\title{
Evolving story: trepanation and self-trepanation to enhance brain function
} Uma história em andamento: trepanação e auto-trepanação para aumentar a função cerebral Charles André

\begin{abstract}
Trepanation has been performed by people interested in enhancing mental power and well-being since the early 1960 s. The pioneers and main proponents of the procedure are described here. The phenomenon appeared in Europe after a Dutch former medical student published a psychoactive drug-friendly scroll suggesting trepanation as a form of permanently increasing cerebral blood volume and function. He trepanned himself in 1965. Three of his friends became enthusiasts. They also submitted themselves to the procedure and published films and books describing their experiences. Two of them coauthored papers, in collaboration with Russian researchers, and created institutions to promote discussion on trepanation. One of these institutions organized trips to Central and South America to get the operation done. Dozens of people nowadays look for trepanation as a method of spiritualization and increasing well-being and mental power. The phenomenon has an uncertain future, however, as the main proponents and supporters are aging.
\end{abstract}

Keywords: trephining; psychotropic drugs; self-injurious behavior; anthropology, cultural.

\section{RESUMO}

Trepanação vem sendo feita por pessoas em busca de aumento da capacidade mental e bem estar desde a década de 1960. Os pioneiros e maiores proponentes do procedimento são aqui descritos. O fenômeno surgiu na Europa estimulado pela publicação de um manuscrito psicodélico e pela auto-trepanação feita por um ex-aluno de Medicina holandês, já falecido. Três amigos se tornaram entusiastas e também se submeteram a trepanação, apresentando o procedimento e descrevendo seus efeitos em livros ou filmes de certa repercussão. Dois deles criaram organizações de difusão e discussão sobre o tema, e uma destas instituições agencia e organiza viagens a países da América Central e do Sul para interessados. Trepanação foi feita até aqui com estes propósitos em dúzias de pessoas. 0 fenômeno tem, porém, futuro incerto, dado o envelhecimento de seus principais entusiastas.

Palavras-chave: trepanação; psicotrópicos; comportamento autodestrutivo; antropologia cultural.

- Linda and me came over for dinner once and John said, "You fancy getting the trepanning thing done?" I said, "Well, what is it?" He said, "You kind of have a hole bored in your skull and it relieves the pressure." We're sitting at dinner and this is seriously being offered! Now this wasn't a joke, this was like, "Let's go next week, we know a guy who can do it and maybe we could all go together." So I said, "Look, you go and have it done, and if it works, great. Tell us all about it and we'll all have it."

Paul McCartney, 1986 (Musician Magazine Interview)

Trepanation is an ancient surgical procedure, perhaps the first one done frequently (along with limb amputation and circumcision), dating back 7,000 to 10,000 years. The operation has been well documented in Europe, Africa, Asia, and Meso and South America ${ }^{1,2}$. In ancient cultures, it was performed for alleged mystic or religious reasons (e.g., demonic possession) but also for the treatment of madness, severe headaches and other chronic ailments ${ }^{3}$. It has been estimated that up to $6 \%$ of people were trepanned in some populations $s^{4,5}$. Although non-medical and ritualistic motivations for the procedure have been amply suggested, traumatic brain injury appears to have been one of the major reasons ${ }^{5,6}$.

The surgical act (single or multiple holes drilled, mainly in the frontal or parietal regions) was made with careful avoidance of muscles, brain meninges and the brain itself. Estimated survival rates reached $40 \%$ for early procedures, a figure that probably increased to around $80 \%$ during the sixteenth to seventeenth centurie ${ }^{4,6}$. It is a well-documented procedure in Oceania and Africa well into the twentieth century, with an estimated survival of more than $90 \%{ }^{7.8}$. There is good documentation of the tools used and of the antiseptic precautions regularly taken by witch doctors.

Universidade Federal do Rio de Janeiro, Faculdade de Medicina, Departamento de Neurologia, Rio de Janeiro RJ, Brasil.

Correspondence: Charles André; Rua Visconde de Pirajá, 414 / sala 821; 22410-002 Rio de Janeiro RJ, Brasi; E-mail: dr.charles.andre@gmail.com Conflict of interest: There is no conflict of interest to declare.

Received 03 February 2017; Accepted 13 February 2017. 
The use of trepanation in Western medicine has its main roots in Egyptian and Greek practices for the treatment of traumatic brain injury ${ }^{9,10,11,12}$. The procedure was regularly done during the Roman Empire (Celsius), throughout the Middle Ages and beyond ${ }^{3,10}$. Figures declined sharply in the second half of the nineteenth century, paralleling the increasing shift to in-hospital care ${ }^{13}$.

A putative increase in mental power was first used as a justification for trepanation (including self-operation) in recent times in the Western world. In the 1960s and 1970s, a huge interest in methods to "open the mind" and increase perception and insight developed. Mostly, this was attempted pharmacologically, with LSD, marijuana, peyote and other hallucinogens. However, a much smaller group opted for trepanation, a more radical and definitive approach as an answer to that need. This initially included rock musicians, artists, and current or former drug users. Trepanation to enhance brain function is still being performed on dozens of individuals nowadays. In fact, there are institutions that facilitate access to it and promote research on the theme. Current interest in trepanation is found both in North America and Europe. I describe here some of the main personages of this social phenomenon.

\section{HUGO BART HUGES (1934-2004)}

The pioneer and most influential proponent was "Professor Huges". This Dutch librarian was refused a medical diploma in Amsterdam, either because of his advocacy of the alleged psychiatric benefits of marijuana, or because of his failure to pass the obstetric exams. Huges had long been interested in trepanation as a method of surpassing psychological problems and achieving a higher level of consciousness. The theory was based on the concept that an infant's putative higher state of consciousness is related to its unsealed skull allowing free expansion of the brain and hence of cerebral blood flow and metabolism. As we grow older, sutures limit this expansion and flow becomes restricted, even more so because of our upright stance. Methods that increase cerebral blood flow such as jumping, passing from a hot tub to a cold one or using psychoactive drugs like LSD would only temporarily reverse this problem. Trepanning, on the other hand, would allow a persistent increase in blood volume and restore pulsation and metabolism as a result of the increased cranial compliance. This would lead to a higher state of perception and conscience - although perhaps not as intense as that induced by pharmacological methods.

Huges successfully trepanned himself with an electric drill in January 6, 1965 (Figure 1). He affirmed the beneficial
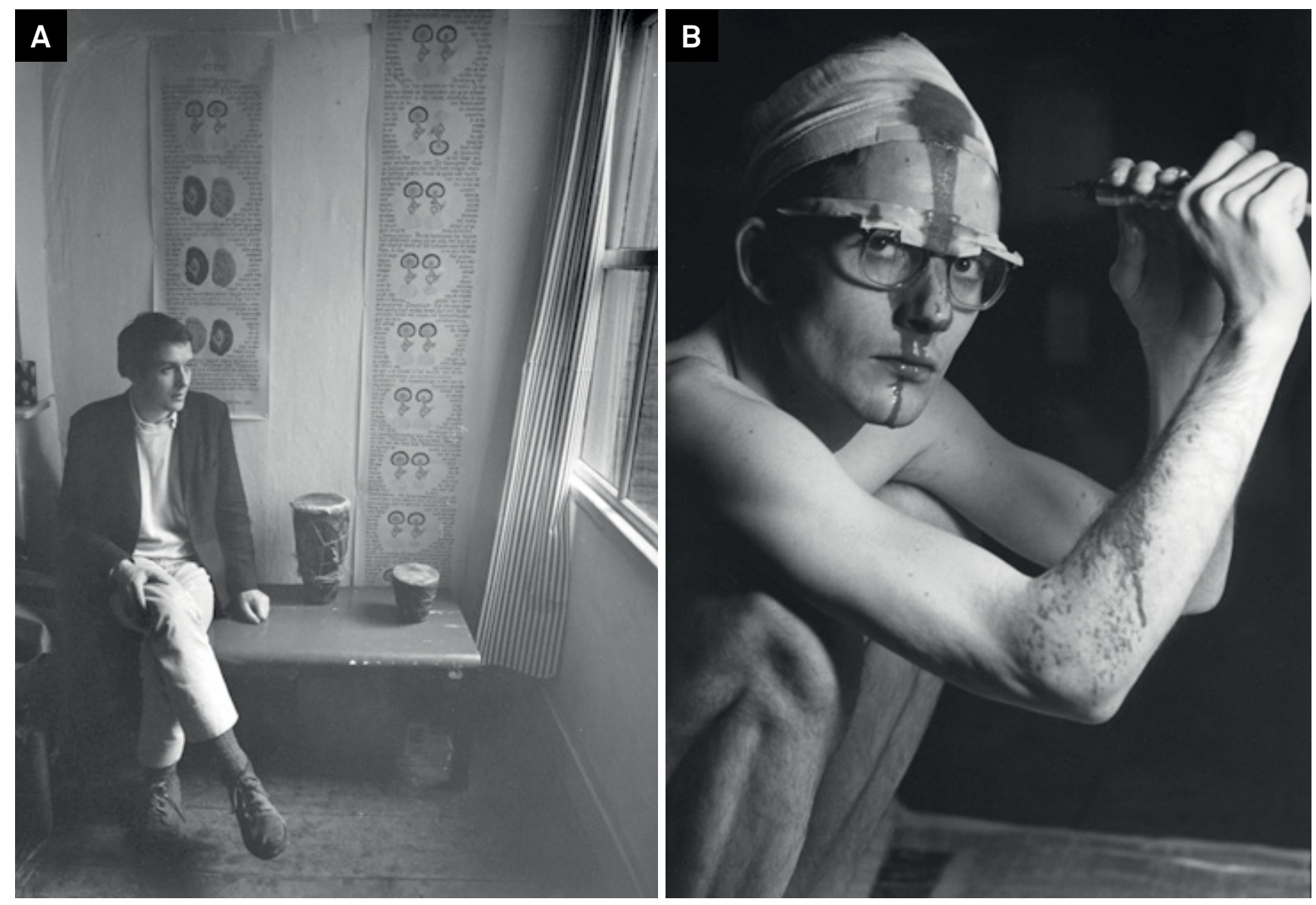

Figure 1. Hugo Bart Huges: a. Huges and his scroll. b. Self-trepanation. Photos by Cor Jaring (www.madscientistblog.ca/madscientist-6-bart-buges/\#sthash.JNSVuOjN.dpbs). 
effects were immediate: his consciousness was heightened and his neuroses had been overcome. He started to preach about trepanation (e.g., John Lennon considered being trepanned after talking to him $^{14,15}$ ) and published documents on it, the most influential being "Homo Sapiens Correctus (The Mechanism of Brainbloodvolume)" in 1962, a manuscript scroll in which he discusses the benefits of the procedure and its mechanisms (sidebar) ${ }^{16}$. He also published a book called "Trepanation (looking for treatment for insanity)" in 1971 and an autobiographic book ("With the Hole") in 1972. Huges died at age 70, possibly from heart disease.

\section{JOSEPH MELLEN (1939-)}

The English citizen Joey Mellen first met Huges in Ibiza after dropping out of Oxford University and rapidly became a close friend and follower. After some years talking about trepanation, he decided to act. The first two attempts were made under the influence of LSD, using local anesthesia and a manual corkscrew bought in a surgical store. After the first unsuccessful attempt, he asked for the help of Amanda Feilding (discussed below), but at the final moment he fainted and was briefly hospitalized and then imprisoned for possession of marijuana. He finally succeeded in completing the trepanation soon after and described the immediate effects as bubbling and schlurping noises ${ }^{17}$. Despite his apparent success (a small and asymmetric piece of bone was collected), he doubted whether the well-being that followed was really related to the small hole made. In 1970, he made a second hole (now with an electric drill). This was deemed most satisfactory, as it was at least one inch deep and much pulsating blood came out. The mental effects were also the expected, as he felt his spirits progressively rising until he reached a feeling of perennial freedom and serenity. All this experience is described in a book called "Bore Hole" (1970), which has recently been reissued (Figure 2).

\section{AMANDA FEILDING (1943-)}

This successful English artist and gallerist of noble ascent (now the Countess of Wemyss and March, by marriage) was long interested in mysticism and psychology. Joseph Mellen introduced her to Huges in 1966. At that time, she (also an Oxford dropout) was already sharing her flat in London with Mellen. She went to Amsterdam and had a relationship with Huges. When she came back to London, she was so impressed by the evident changes in Mellen's personality soon after his final and successful trepanation that she decided to have it herself. The messy procedure was documented in a short, hard-to-find cult film ("Heartbeat in the Brain"). Feilding and Mellen bought and ran an art gallery ${ }^{18}$. They lived together up to the early 1990s and had two sons (born in 1979 and 1985).
After their separation, both convinced their next partners to trepan themselves ${ }^{19}$. She apparently had the trepanation redone two decades later because of bone regrowth ${ }^{14}$.

Feilding published a book on trepanation ("Blood and Consciousness”, 2001) and ran twice (1979 - 40 votes, 1983 - 139 votes) for British Parliament, with a platform fighting specifically for public funding of trepanation ("Trepanation for the National Health") (Figure 3A). She now financially supports and co-authors Russian researchers on the relationships between blood and cerebrospinal fluid dynamics and consciousness ${ }^{20,21,22}$, and supports research on consciousness and psychoactive drugs and the creation of balanced drug policies via the Beckley Foundation (http://beckleyfoundation.org).

\section{PETER HALVORSON (1947?-)}

Peter Halvorson is an American diamond-setter and farm-owner in Pennsylvania. In his twenties, he suffered from depression and dropped out of the University of Cincinnati in 1968. Halvorson met Huges and finally trepanned himself with an electric drill in 1972 in Amsterdam (Figure 3B). The operation led to increased energy, focus and drive, and he was convinced that it could frequently lead to freedom from antidepressants and psychotherapy. In an interview

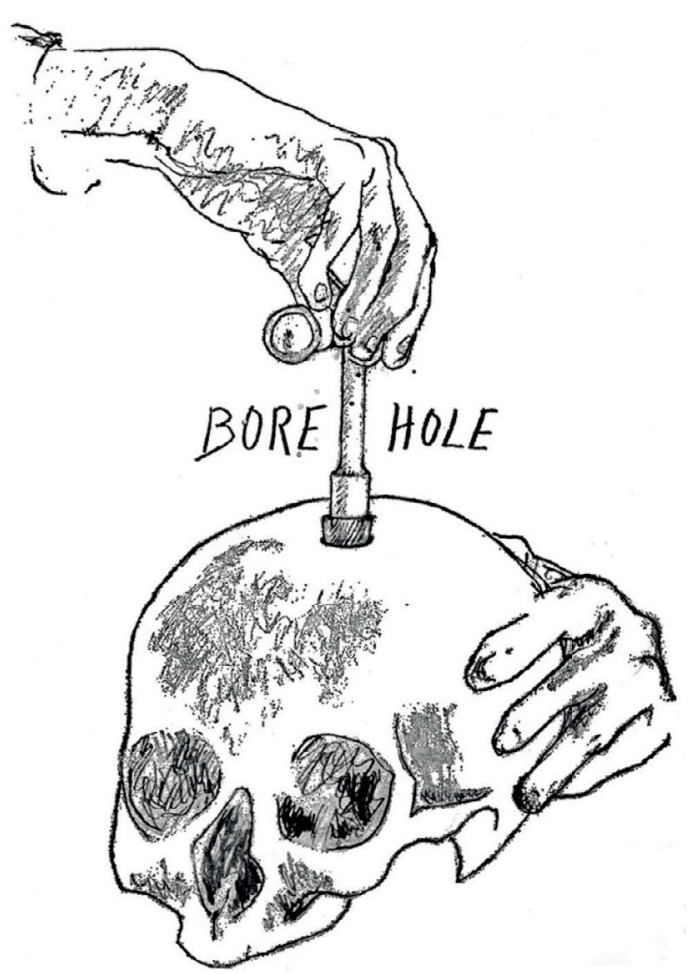

Figure 2. Cover from the first edition of "Bore Hole" by John Mellen (www.vice.com/read/meet-the-man-who-drilleda-hole-in-his-own-skull-to-stay-high-forever.). The first sentence of the book reads: 'This is the story of how I came to drill a hole in my skull to get permanently high'17. 

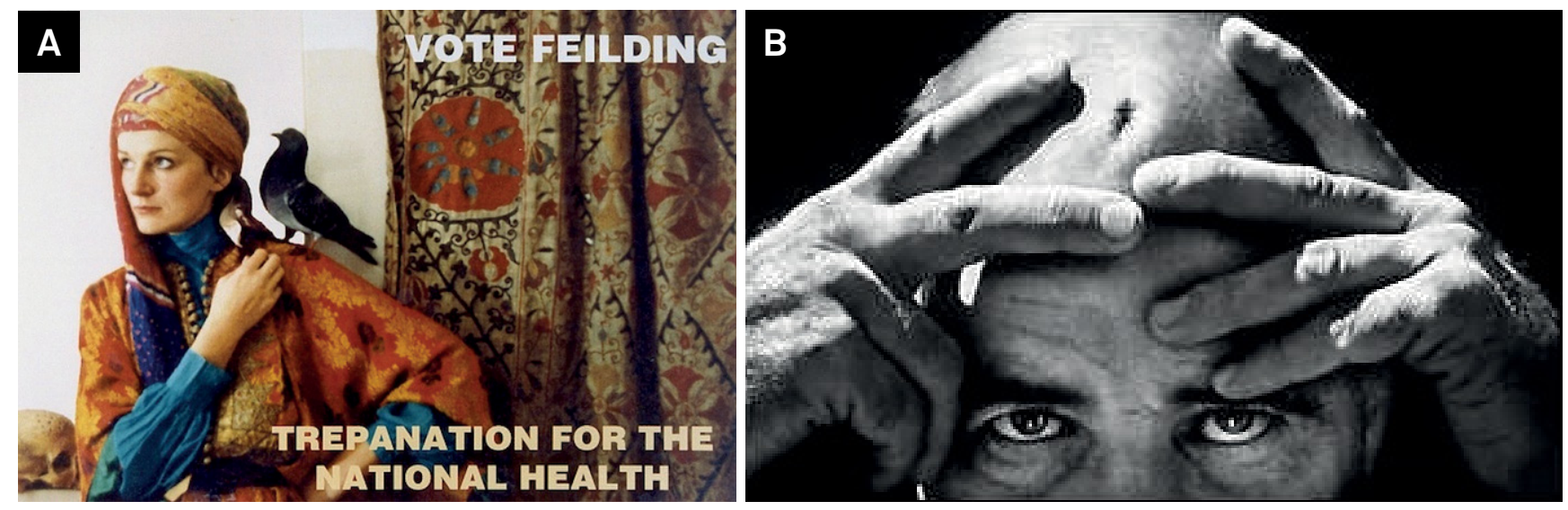

Figure 3. Amanda Feilding and Paul Halvorson. a. Amanda Feilding's campaign poster. (www.vice.com/read/meet-the-man-whodrilled-a-hole-in-his-own-skull-to-stay-high-forever.) b. Peter Halvorson. Photo by M Williamson (www.washingtonpost.com/wpsrv/style/features/trepan.htm).

in 1998, he estimated that several dozen people had already done the operation ${ }^{19}$. At least once he helped a young lady, Heather Perry, to trepan herself in England (2000). He and William E. Lyons pled guilty to the unlicensed practice of medicine and were put in jail (2001), despite Perry's testimony on the positive effects of the procedure ${ }^{14,19,23,24}$.

Halvorson created the International Trepanation Advocacy Group (ITAG) in 1997. As stated in its official site, the original mission was to provide information about the procedure (www.trepan.com). From 2000 to 2004, the ITAG established relations with medical facilities and funded a pilot study of 15 volunteers submitted to elective trepanation in Mexico. The study could not prove physiological changes using MRI methods (not described) but all the individuals are said to be satisfied with the procedure. Halvorson and Feilding coauthored a number of studies on brain blood and cerebrospinal fluid dynamics $20,21,22,25$. The one most quoted by the ITAG (a translation from an article first published in Russian) concerns people submitted to neurosurgery for different and unstated reasons ${ }^{20}$. The fight for scientific proof of the effects of trepanation did not prevent the ITAG from actively helping interested individuals to undergo the procedure. In fact, even today, it is actively getting people operated on abroad (now in Ecuador) in a kind of medical tourism, whose particulars - trip, facilities, staff, and cost - are easily found ${ }^{26}$.

\section{FINAL REMARKS}

Except for Huges, none of the other persons mentioned in this article seems to have made an open apology for self-trepanation. However, all of them actually helped others in their selfoperations. Also, there are other reports of individuals doing it in their houses, with support of friends and with variable psychic effects ${ }^{23}$. Based on interviews made with individuals who had undergone trepanation decades earlier or more recently, and even though many of the pioneers had been actively using
LSD and other psychoactive drugs when they were operated upon, no overt sign of disruptive mental disease can be found in most people who voluntarily submitted to the procedure ${ }^{24}$.

After this initial heroic phase, however, the main proponents of trepanation turned their efforts towards legitimizing the procedure and its institutionalization. Funding for research and publication in scientific magazines and the democratic fight for its legalization in England are examples of this phenomenon in recent decades ${ }^{27}$. Researchers from the I.M. Sechenov Institute of Evolutionary Physiology and Biochemistry, St. Petersburg, published a number of papers coauthored by Feilding and Halvorson and, with funding provided by their foundation, evaluated changes in cranial compliance and blood flow after craniectomy or during aging $20,21,22,23,24,25$. The ITAG supported another unpublished study evaluating MRI changes in 15 people who voluntarily submitted to trepanation, and its site includes pdf versions of studies on perivascular cerebrospinal fluid dynamics presented as supportive evidence for trepanation.

The interest in trepanation may or may not decline after major enthusiasts or proponents such as Feilding and Halvorson die. However, despite great resistance from the medical profession in the USA and Europe, authorities eventually made favorable comments ${ }^{27}$, and there are reports of trepanation being done by neurosurgeons in a number of countries ${ }^{19,24,26}$. People are actively invited by organizations such as the ITAG to get the procedure done in Mexico or in Ecuador ${ }^{23,26}$.

The disease burden related to drug use is increasing worldwide ${ }^{28}$. Hallucinogen use is considered a core element of relatively well-structured religions, such as the Brazilian Amazon Santo Daime Church. Interest on the beneficial psychic effects of ayahuasca is actually increasing in Europe and North America, as are reports of intoxication from the drug ${ }^{29,30}$. Also, a naive belief in "scientifically supported" information, especially among internet fans, and a persistent interest in mystic theories such as the third eye, may contribute to creating a favorable scenario that increasingly incites people to 
resort to radical acts such as trepanation. In addition, even nowadays, traditional medicine may lead to unexpected and extreme treatments being given for epilepsy or other diseases ${ }^{31}$.

In conclusion, the wide availability of information on the Web, the relative success of internet videos and interviews with pioneers and proponents of trepanation, and modern day interest in easy solutions for difficult problems such as chronic depression and social maladaptation may boost the search for trepanation in the future. Doctors should be aware of this, as they may be surprised in the emergency room by complications from self-operation. Or by someone entering their offices and gently asking: "Doctor, would you please make a hole in my head?"

\section{References}

1. Collado-Vázquez S Carrillo JM. Cranial trepanation in The Egyptian. Neurologia. 2014;29(7):433-40. https://doi.org/10.1016/j.nrleng.2011.05.008

2. MajmundarNJ, Assina R, Prestigiacomo CJ, Gandhi CD. Neurosurgery in ancient India: susruta. Indian J Neurosurg. 2015;4(2):117-23. https://doi.org/10.1055/s-0035-1558839

3. Paciaroni M, Arnao V. Neurology and war: from antiquity to modern times. In: Front Neurol Neurosc. 2016;38:1-9. https://doi.org/10.1159/000442562

4. Rifkinson-Mann S. Cranial surgery in ancient Peru. Neurosurgery. 1988;23(4):411-6. https://doi.org/10.1227/00006123-198810000-00001

5. Faria MA. Neolithic trepanation decoded-A unifying hypothesis: has the mystery as to why primitive surgeons performed cranial surgery been solved? Surg Neurol Int. 2015;6(1):72. https://doi.org/10.4103/2152-7806.156634

6. Andrushko VA, Verano JW. Prehistoric trepanation in the Cuzco region of Peru: a view into an ancient Andean practice. Am J Phys Anthropol. 2008;137(1):4-13. https://doi.org/10.1002/ajpa.20836

7. Meschig R, Schadewaldt H, Kiwit J. Schädeloperationen bei den Kisii (Gusii) im Hochland Westkenias. Dtsch Med Wochenschr. 1980;105(52):1817-21. https://doi.org/10.1055/s-2008-1070966

8. Rawlings CE 3rd, Rossitch EJr. The history of trephination in Africa with a discussion of its current status and continuing practice. Surg Neurol. 1994;41(6):507-13. https://doi.org/10.1016/0090-3019(94)90018-3

9. Kamp MA, Tahsim-Oglou Y, Steiger HJ, Hänggi D. Traumatic brain injuries in the ancient Egypt: insights from the Edwin Smith Papyrus. J Neurol Surg A Cent Eur Neurosurg. 2012;73(4):230-7. https://doi.org/10.1055/s-0032-1313635

10. Gurdjian ES. The treatment of penetrating wounds of the brain sustained in warfare: a historical review.J Neurosurg. 1974;40(2):157-67. https://doi.org/10.3171/jns.1974.40.2.0157

11. Tsermoulas G, Aidonis A, Flint G. The skull of Chios: trepanation in Hippocratic medicine.J Neurosurg. 2014;121(2):328-32. https://doi.org/10.3171/2014.4.JNS131886

12. Tulio E. Trepanation and Roman medicine: a comparison of osteoarchaeological remains, material culture and written texts. J R Coll Physicians Edinb. 2010;40(2):165-71. https://doi.org/10.4997/JRCPE.2010.215

13. Gross CC. Trepanation from the paleolithic to the internet. In: Arnott R, Finger S, Smith CVM, editors. Trepanation: history, discovery, theory. Lisse: Swets \& Zeitlinger B.V; 2003. p. 307-22.

14. Costandi M. Lunch with Heather Perry. ScienceBlogs: neurophilosophy. 2008 Aug 4 [cidet 2016 Dec 8]. Available from: http://scienceblogs. com/neurophilosophy/2008/08/04/lunch-with-heather-perry/

15. Salewicz C. Paul McCartney Can't Let It Be. Musician Magazine. Oct 1986 [cited 2016 Dec 8];(96):56. Available from: http://vinylbeatz. blogspot.com.br/2015/08/musician-magazine-october-1986.html

16. Hartshorn M. Mad Scientist \#6: Bart Huges. Mad Scientist Blog: an encyclopaedia of science madness. Jan 7, 2011 [cited 2016 Dec 8]. Available from: : http://www.madscientistblog.ca/mad-scientist-6bart-huges/\#sthash.tYLqQCcJ.dpbs

17. Doran J.I drilled a hole in my own skull to stay high forever. Vice. Feb 12, 2016 [cited 2016 Dec 8]. Available from: http://www.vice.com/read/meetthe-man-who-drilled-a-hole-in-his-own-skull-to-stay-high-forever
18. Michell J. Eccentric Lives, peculiar notions. New York: Black Dog \& Leventhal; 2002.

19. Colton M. You need it like...a hole in the head? Washington Post. May 31, 1998 [cited 206 Dec 8]. Available from: http://www. washingtonpost.com/wp-srv/style/features/trepan.htm

20. Moskalenko YE, Weinstein GB, Kravchenko TI, Mozhaev SV, Semernya VN, Feilding A et al. [The effect of craniotomy in the intracranial hemodynamics and cerebrospinal fluid dynamics in humans]. Fiziol Cheloveka. 2008;34(3):299-305. Russian.

21. Moskalenko YE, Kravchenko TI, Vainshtein GB, Halvorson P, Feilding A, Mandara A et al. Slow-wave oscillations in the craniosacral space: a hemoliquorodynamic concept of origination. Neurosci Behav Physiol. 2009;39(4):377-81. https://doi.org/10.1007/s11055-009-9140-8

22. Moskalenko YE, Vaĭnshteĭn GB, Riabchikova NA, Halvorson P, Fielding A, Kravchenko TI et al. [Interhemisphere asymmetry of the CSF dynamics and biomechanical properties of the skull]. Ross Fiziol Zh Im I M Sechenova. 2010;96(10):1005-1013. Russian.

23. Chilman T. Why it's an awfully good idea to drill a hole in your head. 2016 [cited 2016 Dec 10]. Available from: http://www.academia. edu/4612140/Why_Its_an_Awfully_Good_Idea_To_Drill_a_Hole_ in_Your_Head

24. Resz N. Trepanation. The Santa Clara. May 1, 2003 [cited 2016 Dec 2]. Available from: http://thesantaclara.org/trepanation/\#.WEFpF7IrLIU

25. Moskalenko YE, Ryabchikova NA, Weinstein GB, Halvorson P, Vardy TC. Changes of circulatory metabolic indices and skull biomechanics with brain activity during aging. J Integr Neurosci. 2011;10(2):131-60. https://doi.org/10.1142/S021963521100266X

26. The goodnews letter. 2011 [cited 2016 Dec 10]. Available from: http://www.trepan.com/wp-content/uploads/2016/04/2016Trepanation-Newsletter.pdf

27. Levy G. The Cannabis Countess: why is eccentric who drilled a hole in head to get high supported by the Government's drugs czar? Mail Online. April 10, 2010 [cited 2016 Dec 6]. Available from: http://www. dailymail.co.uk/news/article-1264891/Mick-Jaggers-friend-drilledhole-head-high-supported-Governments-drugs-czar.html

28. Kassebaum NJ, Arora M, Barber RM, Bhutta ZA, Brown J, Carter A et al. Global, regional, and national disability-adjusted life-years (DALYs) for 315 diseases and injuries and healthy life expectancy (HALE), 1990-2015: a systematic analysis for the Global Burden of Disease Study 2015. Lancet. 2016;388(10053):1603-58. https://doi.org/10.1016/S0140-6736(16)31460-X

29. Kavenská V, Simonová H. Ayahuasca tourism: participants in Shamanic Rituals and their personality styles, motivation, benefits and risks. J Psychoactive Drugs. 2015;47(5):351-9. https://doi.org/10.1080/02791072.2015.1094590

30. Heise CW, Brooks DE. Ayahuasca exposure: descriptive analysis of calls to US poison control centers from 2005 to 2015. J Med Toxicol. 2016. https://doi.org/10.1007/s13181-016-0593-1

31. Mohammad Y, Al-Hussain F, Hussain S, Al Raddadi KK. Traditional treatment of epilepsy: trepanation revisited. Neurology. 2016;87(10):1064. https://doi.org/10.1212/WNL.0000000000003069 


\section{BRAIN BLOOD VOLUME}

\section{THE MECHANISM OF BRAIN BLOOD VOLUME}

\section{The Large Mechanism:}

I. Man's position is upright. II. The cranium seals at the end of growth. III. Blood is heavier than cerebrospinal fluid. These three factors cause the brainbloodvolume to decrease as a mouthful of cerebrospinal fluid replaces it. The brainmetabolism slows down, originality and creativity diminish, youth has come to an end. By an increase of the brainbloodvolume the metabolism is accelerated, due to the intake of more oxygen and glucose from the blood and the output of more carbon dioxide to the blood, and more brain functions, including consciousness, are improved. The Handstand: Stand on your head for ten minutes. The columns of blood and cerebrospinal fluid that press on the cranial cavity in that position differ in length, the column of cerebrospinal fluid reaching only the base of the spine. In the cranial cavity, the blood capillaries expand slowly, whilst cerebrospinal fluid is pressed out and the brainmetabolism remains at higher level for several hours. The Handgrip: Keep the neck veins closed with two fingers pressed against the windpipe. Maintain the grip with short interruptions for ten minutes. The capillaries in the cranial cavity are filled with more blood by the force of the heart and an equal volume of cerebrospinal fluid is pressed out of the central nervous through the nerve channels. Pressing Up: Apply the handgrip, keep the abdomen contracted, exhale and suck vigorously as much blood as possible from the body to the lungs. Now inhale deeply, release the hand-grip and press the blood out of the lungs. The bigger volume of blood the heart pumps out after that meets an increased resistance from the abdominal contraction and more blood finds its way into the cranial cavity than by means of the hand grip alone. Osmotical: For a few days eat very little protein and then so much of it, that the blood gets overloaded with urea, the main product of protein metabolism. This attracts by osmotical means a portion of the cerebrospinal fluid, instead of which an equal volume of extra blood remains "hanging" in the cranial cavity. Operatively: The effect of making a hole in the skull is to restore the expansion possibilities of the brain membranes. History: The trepanation hole in each of the many skulls found together in Peruvian tombs show that the operation was part of the initiation into a higher caste. It is still a common practice in parts of Central Africa. With today's knowledge of operating techniques one can easily do this by oneself. The Adrenal Reflex: After a hot bath take a cold bath. By reflex the adrenal glands then release so much adrenaline at once that the brainbloodvolume increase noticeably. With daily use of adrenaline one must provide the raw materials for its synthesis by eating sufficient fruits. Drugs: The brainbloodvolume is also increased by the use of alcohol, but the accelerated brain metabolism leaves the user drunk. Hemp does not lead to narcotic effects, as alcohol does, nor to addiction as tobacco does. Addiction to toxic drugs (narcotics) can lead to death on withdrawal, whereas using the non-toxic "Psychovitamins" (substances that temporarily increase the brainbloodvolume by constricting the neck veins) one will never need more than the standard dose and one can stop at any time without disagreeable after effects. Synthetic psychovitamins like psilocybin, mescaline and L.s.d. produce a bigger increase in the brainbloodvolume than hemp does. As a result of its accelerated metabolism, the brain takes more glucose from the blood. By eating a mouthful of sugar at the onset of agitation or fatigue, one prevents the progressively worse symptoms of hypoglycaemia, such as cold hands, chills, trembling and paranoia, which occur when adrenalin is secreted as an emergency reaction to supply the brain with new glucose from the liver. If no sugar is taken, the action of adrenalin may strain the heart, and when the adrenalin is exhausted, the ego may get lost. By eating enough sugar the experience is made more positive. Pregnancy: The pregnancy hormones constrict the neck veins of the mother.

\section{THE EGO}

\section{The Small Mechanism}

A reflex, by constricting the arteries leading to the rest of the brain, concentrates the brainbloodvolume in the parts of the brain which are in action. (Decreased brainbloodvolume limits the number of brain centres that can function simultaneously, and reduces the volume of blood directed into those centres). A closed circuit is formed by one's perception of the word one speaks as one speaks it perception of the word is simultaneous with the reflex action that concentrates the brainbloodvolume in the speaking centre, word recognition in turn becomes the stimulus that triggers the reflex. A chain of word associations establishes and maintains a priority in the direction of brainbloodvolume to the centres for speaking, listening, writing and reading. Ego Loss: The control of the speaking centre (and the other word-communication centres) over the coordination of the brain functions is a conditioned reflex which is deconditioned not only when the meaning of the word is lost, but also by prolonged "sugarlack", since the reflex action fails to supply the centres with more energy as long as the blood contains too little glucose. 
The Third Eye: Trepanation restores the intra-cranial pressure which is necessary to replace the blood lost to gravity as the cranium sealed, and all brain centres are again able to function independently of the conditioned reflex, still using it for more effective concentration. Origin of The Ego: Talking and the ego are developed by the meaning the parents give to the word. The child is made to change his behaviour at the same time that a formula is repeated in his ears, until the recognition of it in his listening centre causes the change in behaviour. Once conditioned by the formulas the child recognizes them among the sounds he produces himself by the occurrence of the changes in his own behaviour. The ineffectiveness of the child's repetition of the formulas to cause the same behaviour-change in an outside projected image of himself makes his own reaction dependent on whether he identifies with himself or with the image. Identification with the image is effected by a constriction of the arteries to the parts of the brain that are threatening the ego resulting in repression from consciousness and exclusion from function. 